Institute of $\mathbf{F}_{\text {ood and }} \mathbf{A}_{\text {gricultural }} \mathbf{S}_{\text {ciences }}$

\title{
Tropical Soda Apple Making a Comeback ${ }^{1}$
}

\section{Pat Hogue and Jeff Mullahey ${ }^{2}$}

The environmental conditions of the last couple of years have apparently helped to not only give us less forage for our cattle to consume, but also to enhance the ability, once again, of Tropical Soda Apple (TSA), solanum viarum, to gain a strong foothold. The first sighting of TSA in South Florida was in 1987, but it wasn't until the early 1990s that the population of this invasive weed really exploded following an extended period of drought (87-89) much like the last couple of years.

We are once again seeing a dramatic increase in the TSA population in pastures, and again in locations where it had not been previously or was thought to be under control. Tropical Soda Apple is on the invasive species lists of both the State and Federal governments; and in Florida, as such, it is illegal to knowingly transport the plant or plant parts, including seeds, to other locations where it may become established. This could be a major limitation for selling sod. Some southern states already have or are considering cattle quarantine regulations for cattle coming from TSA-infested areas. Because selling of sod from cattle operations in South Florida is so predominant and the number of calves being shipped is going to be increasing, it is logical that we review the current control methods for TSA for your assistance.

Probably the most important statement that could be made in the control of Tropical Soda Apple is "Do Not Allow Plants to Produce Fruit." TSA is one of the most prolific fruit and seed producers that we could face, producing fruit year round, but mostly from September through May. Each viable fruit may contain 200 - 400 seeds with a germination of $75 \%$ or more. At times a single plant may contain 40,000 to 50,000 viable seed for dispersal by cattle, deer, feral hogs, raccoons and birds that consume the fruit on the plant in addition to those fruit that dropped to the ground. One method to get a stand of TSA under reasonable control is to keep it mowed regularly, not allowing the plants to produce fruit. Mowing periodically to a stubble height of 3" will deplete root reserves and eventually kill part of the stand and render the remaining plants more susceptible to control by herbicides. By not allowing fruit production you eventually limit seeds in the soil for future germination and new plant development.

For dense or heavy infestations of TSA, where spot spraying is not feasible or economically viable, the stand should be mowed to a stubble height of $3 "$

1. This document is WEC 178, one of a series of the Wildlife Ecology and Conservation Department, Florida Cooperative Extension Service, Institute of Food and Agricultural Sciences, University of Florida. Original publication date:May, 2003. Visit the EDIS Web Site at http://edis.ifas.ufl.edu.

2. Patrick J. Hogue, Extention Agent III M.S. Livestock, Okeechobee County; Cooperative Extension Service, and Jeff Mullahey, Professor and Center Director, West Florida Research and Education-Milton; Institute of Food and Agricultural Sciences, University of Florida, Gainesville, 32611.

The use of trade names in this publication is solely for the purpose of providing specific information. UF/IFAS does not guarantee or warranty the products named, and references to them in this publication does not signify our approval to the exclusion of other products of suitable composition.

The Institute of Food and Agricultural Sciences is an equal opportunity/affirmative action employer authorized to provide research, educational information and other services only to individuals and institutions that function without regard to race, color, sex, age, handicap, or national origin. For information on obtaining other extension publications, contact your county Cooperative Extension Service office. Florida Cooperative Extension Service/Institute of Food and Agricultural Sciences/University of Florida/Christine Taylor Waddill, Dean. 
as soon as possible to prevent fruit production.

Repeat mowing when plants reach the flowering stage in about 50 - 60 days through April. Within 50 60 days after the last mowing, when plant growth does not go beyond the flowering stage, broadcast spray the stand in late May to June using Remedy® at 1 quart/A $+0.10 \%-0.25 \%$ nonionic surfactant in 40 gallons of water per acre. Follow the broadcast spraying with spot treatments to control live-over plants and new plants that emerge. Do Not Allow Plants to Produce Fruit.

If you have sparse infestations where individual plants are scattered in pastures, vegetable fields, sod fields, hammocks, ditch banks and road sides, that allow plants to be individually treated, you can follow one of the below recommendations. Although mowing may help get these sparse stands under control, it generally is not necessary or cost effective for sparse stands. These recommendations are for herbicides that currently prove to give $95 \%$ $100 \%$ control in spot application.

- Remedy® @ 0.5\% solution + 0.10\% - 0.25\% nonionic surfactant + color marker.

- Cover the entire plant to insure maximum herbicide uptake and control. Allow 3-4 hours for herbicide to dry before expected rainfall. Monitor areas monthly and treat new plants. Do Not Allow Plants to Produce Fruit.

- To control TSA in pastures other than bahiagrass, where Remedy® may not be labeled, consider using Dicamba @ 2 qt/A + 0.10\% $0.25 \%$ nonionic surfactant in $20-30$ gallons of water. Dicamba (Banvel, Clarity, Vanquish) is effective at controlling TSA, but the 2 qt. rate is more expensive than Remedy®.

To effectively control TSA, you must permanently stop seed production by controlling existing plants in pastures, ditch banks and hammocks. Otherwise, the plant will continue to spread and remain the nuisance and profit robber it has become. For more information on controlling TSA contact your local county extension agent.

For related information on Tropical Soda Apple, please refer to Edis documents WEC 176,
Shipping Cattle, Not Tropical Soda Apple; and WEC 177, Management Practices to Control Tropical Soda Apple. 